\title{
Association between $+45 T>G$ adiponectin polymorphism gene and type 2 diabetes mellitus and metabolic syndrome in a
} Venezuelan population [version 1; peer review: 2 approved, 1 approved with reservations]

\author{
María Patricia Sánchez¹,2, Carem Prieto 1,3, Endrina Mujica1', Kendry Vergara², \\ Enifer Valencia², Eudymar Villalobos², Mayerlim Medina1, Michael Parra4, \\ Rosanna D'Addosio (D) 5 , Kyle Hoedebecke (D)7, Johel E. Rodríguez ${ }^{8}$, \\ Valmore Bermudez ${ }^{9}$

\footnotetext{
${ }^{1}$ Centro de Investigaciones Endocrino-Metabólicas “Dr. Félix Gómez”, Facultad de Medicina, Universidad del Zulia, Maracaibo, Venezuela

2Escuela de Bioanálisis, Facultad de Medicina, Universidad del Zulia, Maracaibo, Venezuela

${ }^{3}$ Carrera de Medicina, Unidad Académica de Salud y Bienestar, Universidad Católica de Cuenca, Cuenca, Ecuador

${ }^{4}$ Escuela de Medicina, Facultad de Medicina, Universidad del Zulia, Maracaibo, Venezuela

${ }^{5}$ Departmento de Salud Pública, Escuela de Medicina, Universidad del Zulia, Maracaibo, Venezuela

${ }^{6}$ Department of Family Medicine, Uniformed Services University of the Health Sciences, APO, Armed Forces Pacific, 96205, USA

${ }^{7}$ Department of Family Medicine, WONCA Polaris, APO, AP, 9605, USA

${ }^{8}$ Facultad de Ingenierías, Universidad Simón Bolívar, Cúcuta, Colombia

9Universidad Simón Bolívar, Facultad de Ciencias de la Salud, Barranquilla, Colombia
}

V1 First published: 14 Mar 2019, 8:292

https://doi.org/10.12688/f1000research.16890.1

Latest published: 14 Mar 2019, 8:292

https://doi.org/10.12688/f1000research.16890.1

\section{Abstract}

Background: Adiponectin (ADIPOQ) is a hormone primarily synthesized by adipocytes and encoded by the ADIPOQ gene, which exerts anti-inflammatory, antiatheratogenic and insulin sensitizing functions. It has been shown that its plasma concentrations are decreased in individuals with metabolic syndrome (MS) and type 2 diabetes mellitus (DM2), which could be due to variations in the gene coding for this protein. The aim of this study was to detect the +45 $\mathrm{T}>\mathrm{G}$ polymorphism of the $A D I P O Q$ gene in subjects with $\mathrm{DM} 2$ and MS in Maracaibo municipality, Zulia state, Venezuela.

Methods: A total of 90 subjects who attended the Center for Metabolic Endocrine Research "Dr. Félix Gómez" were enrolled for this study, 46 of which had MS-DM2 and 44 of which were healthy control individuals. Genomic DNA was extracted from blood samples and PCRrestriction fragment length polymorphism analysis was carried out for the promoter region of the $A D I P O Q$ gene. Likewise, the $+45 \mathrm{~T}>\mathrm{G}$ polymorphism was identified and correlated with MS and DM2 in the studied population.

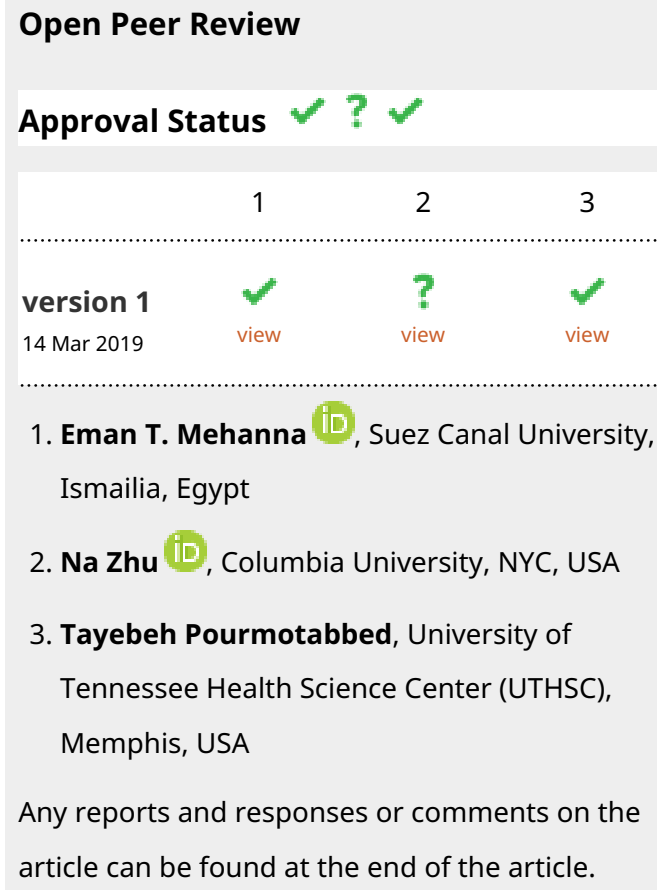

Any reports and responses or comments on the article can be found at the end of the article. 
Results: The most frequent allele in both groups was the T allele, and the predominant genotype was homozygous T/T (79\%). Genotypes with heterozygous T/G and G/G homozygous polymorphism were more frequent in the control group than in the MS-DM2 group. Regarding the individuals with T/G and G/G genotypes, statistically significant lower mean values were found for fasting glucose, total cholesterol, triacylglycerides, abdominal circumference, and for the medians of systolic and diastolic blood pressure. Odds ratio were calculated for the presence or absence of MS and DM2.

Conclusions: The results suggested that the presence of the $\mathrm{G}$ allele exerts a protective effect on the carrier individuals, thus avoiding the appearance of the aforementioned metabolic alterations.

\section{Keywords}

metabolic syndrome, type 2 diabetes mellitus, ADIPOQ gene, polymorphism, DNA

Corresponding author: Kyle Hoedebecke (khoedebecke@gmail.com)

Author roles: Sánchez MP: Conceptualization, Investigation, Methodology, Project Administration, Supervision, Writing - Original Draft Preparation; Prieto C: Formal Analysis, Writing - Original Draft Preparation; Mujica E: Data Curation, Investigation; Vergara K: Data Curation, Investigation; Valencia E: Data Curation, Investigation; Villalobos E: Formal Analysis, Investigation; Medina M: Project Administration, Writing - Original Draft Preparation; Parra M: Project Administration, Writing - Original Draft Preparation; D'Addosio R: Data Curation, Investigation; Hoedebecke K: Resources, Writing - Original Draft Preparation, Writing - Review \& Editing; Rodríguez JE: Data Curation, Formal Analysis; Bermudez V: Conceptualization, Writing - Original Draft Preparation

Competing interests: No competing interests were disclosed.

Grant information: The authors acknowledge the "Consejo de Desarrollo Científico, Humanístico y Tecnológico" (CONDES) of La Universidad del Zulia for the financial support of this project (Project No. CC-0429-16).

Copyright: @ 2019 Sánchez MP et al. This is an open access article distributed under the terms of the Creative Commons Attribution License, which permits unrestricted use, distribution, and reproduction in any medium, provided the original work is properly cited.

How to cite this article: Sánchez MP, Prieto C, Mujica E et al. Association between +45T>G adiponectin polymorphism gene and type 2 diabetes mellitus and metabolic syndrome in a Venezuelan population [version 1; peer review: 2 approved, 1 approved with reservations] F1000Research 2019, 8:292 https://doi.org/10.12688/f1000research.16890.1

First published: 14 Mar 2019, 8:292 https://doi.org/10.12688/f1000research.16890.1 


\section{Introduction}

Adiponectin contains 244 amino acids $^{1}$ and this protein is expressed almost exclusively in white adipose tissues where it has anti-diabetic, anti-inflammatory, and anti-atherogenic properties in addition to cardioprotective effects ${ }^{2,3}$. It is considered one of the most abundantly secreted adipokines by the adipocyte, because its plasma concentrations in humans vary between $5-30 \mu \mathrm{g} / \mathrm{ml}$, and although this values vary according to sex (generally higher in women) $)^{4}$, adiponectin represents $0.01 \%$ of total plasma proteins $^{3}$. Unlike other known adipokines, its levels are decreased in insulin-resistance associated states, such as obesity, type 2 diabetes mellitus (DM2) and metabolic syndrome ${ }^{5}$.

Metabolic syndrome (MS) is a complex of interrelated risk factors for the development of cardiovascular diseases and diabetes mellitus $(\mathrm{DM})^{6}$. The prevalence of MS in the world is very high; $45 \%$ of the population over 50 years old and about $20 \%$ of the population under 50 years of age have $\mathrm{MS}^{7}$. Patients with MS have twice the risk of developing cardiovascular disease in 5 to 10 years after being diagnosed $^{8}$, increasing the risk of myocardial infarction ${ }^{9}$.

Epidemiological studies conducted in the U.S have shown that the general prevalence of MS is $24 \%$ in Caucasian populations, which increases according to age to more than $30 \%$ in people over 50 years of age and more than $40 \%$ in people over 60 years of age ${ }^{10}$. In a study carried out in Maracaibo, Venezuela, the prevalence of MS was $42.7 \%$, presenting men at a higher risk when compared with women; as age increases, the risk also increases progressively. Similarly, diabetic individuals had up to 4 times higher risk of suffering from $\mathrm{MS}^{11}$.

Diabetes mellitus is one of the main causes of morbidity and mortality, as well as an important cardiovascular risk factor and a poor prognosis in patients with established cardiovascular disease $^{12}$. Its prevalence has drastically increased in the last 20 years and it is estimated that by the year 2030 the number of affected will exceed approximately 400 million people ${ }^{12}$, which translates into a $54 \%$ increase $^{13}$.

Some 422 million people suffer from diabetes in the world, totaling one out of every 11 people. It is estimated that in 2012, 1.5 million people died as a direct consequence of diabetes. According to $\mathrm{WHO}$ projections, diabetes will be the seventh greatest cause of mortality in $2030^{14}$. In Venezuela, according to the 2011 Ministry of Public Power of Health, diabetes mellitus represents the fourth-leading cause of death. This data corresponds with WHO data. Furthermore, diabetes mortality projections remain high over the foreseeable future ${ }^{15}$. In an analysis conducted on a Venezuelan population (Maracaibo City, Zulia State) about the DM2 prevalence, it was found that $8.4 \%$ of the evaluated population had the disease, which is similar to that shown in our continent, in the Carmela study, which took in consideration seven cities in Latin America, evaluating more than 11,000 individuals aged between 25 and 64 years; this study reported a general prevalence of $7 \%$, where the one shown in Mexico City stands out (8.9\%) since is higher ${ }^{12}$.
The serum concentration of adiponectin is reduced in individuals with obesity, DM2, insulin resistance, obesity, dyslipidemia and coronary disease ${ }^{16,17}$. With an link to lower lipid oxidation, higher triglyceride content, and reduced levels of insulindependent signaling-reduced concentrations of adiponectin have been noted in the pathophysiology MS and DM2 ${ }^{18}$.

The $A D I P O Q$ gene is located on chromosome $3 \mathrm{q} 27$, consists of 3 exons and is $15.8 \mathrm{~kb}^{\text {long }}{ }^{1}$. Genetic variants in $A D I P O Q$ can lead to substantial changes in adiponectin levels, which provides convincing evidence that subtle alterations in the genetic code can modify the levels of this hormone, large enough to significantly affect the health, as mentioned before ${ }^{1}$. Several studies have determined that different polymorphisms (SNPs) have been located in the adiponectin gene, which can affect both the transcription and the activity of this hormone. Among the most prominent are the polymorphisms $+45 \mathrm{~T}>\mathrm{G},+276 \mathrm{G}>\mathrm{T}$, $-11.377 \mathrm{C}>\mathrm{G}$ and $-11.391 \mathrm{G}>\mathrm{A}^{19}$.

Studies carried out in different populations, associated the $+45 \mathrm{~T}>\mathrm{G}$ polymorphism of the $A D I P O Q$ gene with the development of DM2, insulin resistance, obesity, coronary artery disease and hypoadiponectinemia ${ }^{19}$. Other studies reported that subjects with the $\mathrm{T} / \mathrm{G}$ or $\mathrm{G} / \mathrm{G}$ genotype at position 45 have a higher risk of developing DM2 when compared to those with T/T genotype ${ }^{20}$. Likewise, it has been observed that subjects who present the $\mathrm{G}$ allele of the $+45 \mathrm{~T}>\mathrm{G}$ polymorphism have lower plasma levels of $\operatorname{adiponectin}^{19}$.

Due to such significant findings, this study aimed to determine nucleotide alterations of the $A D I P O Q$ gene, especially the $+45 \mathrm{~T}>\mathrm{G}$ polymorphism and its relationship with DM2 and MS, in adult individuals of the Maracaibo municipality of Venezuela. The study aimed to identify cases of people carrying the alteration indicated in this gene, which could be related to DM2 and MS. In this way, the presence of the polymorphism would serve as a predictor for the development of MS and/or DM2 in the future $^{16,21}$, guaranteeing the possibility that any person with a predisposing genotype can take opportune measures to prevent these diseases.

\section{Methods}

\section{Subjects}

A total of 90 adult individuals, of which 46 had MS-DM2 and 44 were healthy controls, were enrolled in this study, which was carried out from January 2015 to January 2016. Participants were recruited through a mixed strategy. Some individuals were contacted by phone while in remote locations we made contact with the community leaders in order to verify the size and organization of each neighborhood since public records prove inaccurate. After this, we proceeded to draw sectors and blocks, and then, together with the community leaders, contact the members of the selected houses directly. These individuals participated in the Metabolic Syndrome Prevalence Project ${ }^{11}$ of the Metabolic Endocrine Research Center "Dr. Félix Gómez" (CIEM) of the Faculty of Medicine of University of Zulia performed from 2007 to 2008 . The present study size was the 
same as the previous one. The participants signed an informed consent form, where they were explained everything related to the project and the handling of their samples and tests. This research was approved by the CIEM bioethics committee and complies with the Helsinki declaration. The studied subjects were chosen since they met the predetermined inclusion criteria and with the absence of selected exclusion criteria, depicted in Table 1. In order to make the diagnosis of MS and DM2, 2009 Consensus ${ }^{6}$ and $\mathrm{ADA}^{22}$ criteria was used respectively.

\section{Anthropometry, body composition and biochemistry} analysis

The following variables were measured in the subjects:

1. Waist circumference: taken with a graduated measure tape in centimeters at an equidistant point between the costal margin and the anterior superior iliac spine.

2. Body mass index: estimated by dividing the kilograms of weight by the square of the height in square meters $\left(\right.$ BMI $\left.=\mathrm{kg} / \mathrm{m}^{2}\right)$. A TANITA electronic scale was used to obtain the body weight. To measure the size, a height rod was used.

3. Blood pressure: measured by the auscultatory method, for which a calibrated and properly validated sphygmomanometer was used.

4. Levels of fasting glucose, total cholesterol, triacylglycerides and HDLc (cholesterol bound to high density lipoproteins): (previous fasting from 8 to 12 hours), for which $5 \mathrm{~cm}^{3}$ of blood was drawn from each individual obtained by antecubital venipuncture, which was placed in test tubes and centrifuged to $4000 \mathrm{rpm}$ for 10 minutes. After this, the serum was extracted and placed in polypropylene test tubes for subsequent freezing at $-70^{\circ} \mathrm{C}$. The time between taking the sample and processing did not exceed three months. To determine the fasting glucose, an enzymatic-glucose-colorimetric enzyme kit (Glucose Liquicolor Ref. 10260300, Human Diagnostics) was used. For the quantification of total cholesterol, triacylglycerides and HDLc, commercial enzyme-colorimetric kits (Cholesterol Liquicolor Ref. 10028300; Triacylglicerides liquicolor mono Ref. 10724300; HDL Cholesterol liquicolor Ref. 10084300; all from Human Diagnostics) were used.

5. Low-density lipoprotein bound to cholesterol (LDLc), calculated by the Friedelwald formula: $($ LDL-c $=$ total cholesterol - $(\mathrm{VLDL}=\mathrm{c}+\mathrm{HDL}-\mathrm{c})$, where VLDL-c $=$ triacylglycerides $/ 5(\mathrm{mg} / \mathrm{dl})$ (provided that the triacylglycerides cannot exceed $400 \mathrm{mg} / \mathrm{dl}$ ).

6. Ultrasensitive CRP (usCRP): Turbidimetric method with latex for the quantitative determination of $C$ Reactive Protein (CRP hs Turbitest AA Ref. 1683263, Wiener lab).

7. Homeostatic model assessment of insulin resistance (HOMA-IR): estimated using HOMA with the following formula: HOMA-IR = fasting insulin $(\mu \mathrm{IU} / \mathrm{ml}) \times$ fasting glucose $(\mathrm{mg} / \mathrm{dl}) / 405$, where ELISA methodology was used to determining fasting insulin (Insulin ELISA Ref. EIA2935 DRG International, Inc.)

\section{Genotyping of the $45 \mathrm{~T}>\mathrm{G}$ polymorphism of the ADIPOQ gene}

Genomic DNA extraction. A total of $5 \mathrm{ml}$ peripheral blood (with EDTA as an anticoagulant) was obtained by venipuncture. For DNA extraction, the combined DNA-Salting out extraction technique was used, as described previously ${ }^{23}$, of the Molecular Genetics laboratory of the Medical Genetics Unit of the Faculty of Medicine was used.

PCR amplification of $45 T>G$ polymorphism of the ADIPOQ gene. A 372 bp DNA fragment covering the region of

Table 1. Eligibility criteria for each studied group.

\begin{tabular}{|l|c|c|}
\hline & Healthy controls group & DM2+ MS group \\
\hline Age & $>18$ years old & $>18$ years old \\
\hline WC & $\begin{array}{r}<98.15 \mathrm{~cm} \text { males and } \\
<91.50 \mathrm{~cm} \text { females }\end{array}$ & $\begin{array}{c}\geq 98.15 \mathrm{~cm} \text { males and } \\
\geq 91.50 \mathrm{~cm} \text { females }\end{array}$ \\
\hline SBP & $<130 \mathrm{mmHg}$ & $\geq 130 \mathrm{mmHg}$ \\
\hline DBP & $<85 \mathrm{mmHg}$ & $\geq 85 \mathrm{mmHg}$ \\
\hline HDLC & $\begin{array}{l}\geq 40 \mathrm{mg} / \mathrm{dl} \mathrm{males} ; \\
\geq 50 \mathrm{mg} / \mathrm{dl} \mathrm{females}\end{array}$ & $<40 \mathrm{mg} / \mathrm{dl} \mathrm{males;}$ \\
\hline FG & $<126 \mathrm{mg} / \mathrm{dl}$ & $\geq 126 \mathrm{mg} / \mathrm{dll}$ \\
\hline TG & $<150 \mathrm{mg} / \mathrm{dl}$ & $\geq 150 \mathrm{mg} / \mathrm{dl}$ \\
\hline Diagnosis of DM2+ MS & Absent & Present \\
\hline $\begin{array}{l}\text { Pharmacologic treatment for DM2 and } \\
\text { or metabolic conditions }\end{array}$ & Absent & Present \\
\hline
\end{tabular}

a Regarding Maracaibo, Venezuela these values are adjusted to the population ${ }^{11}$.

WC, Waist circumference; SBP, Systolic Blood Pressure; DBP, Diastolic Blood Pressure; HDLc, Cholesterol bound to high density lipoproteins; FG, fasting glucose; TG, triacylglycerides; DM2, type 2 diabetes mellitus; MS, metabolic syndrome. 
interest was amplified by PCR, using this set of oligonucleotide primers: F5'-GAATGAGACTCTGCTGAGATGG-3' and R5'TATCATGTGAGGAGTGCTTGGATG-3' to amplify the region of interest (Figure 1). The amplification conditions were the following: $95^{\circ} \mathrm{C}$ for $6 \mathrm{~min}$, followed by 35 cycles of $95^{\circ} \mathrm{C}$ for $1 \mathrm{~min}, 45 \mathrm{sec}$ at $56^{\circ} \mathrm{C}$ and $45 \mathrm{sec}$ at $72^{\circ} \mathrm{C}$ and a final extension at $72^{\circ} \mathrm{C}$ for $5 \mathrm{~min}^{24}$. For the amplification reactions, taq DNA polymerase from Promega was used.

RFLP for the detection of the $45 T>G$ polymorphism of the ADIPOQ gene. The amplified fragment of $372 \mathrm{bp}$ was subjected to restriction analysis with the SmaI enzyme. A non-digested fragment (molecular weight, $372 \mathrm{bp}$ ) corresponded to the homozygous T/T genotype. The homozygous G/G genotype was evidenced by the presence of two fragments, one $219 \mathrm{bp}$ and the other $153 \mathrm{bp}$. The product of the digestion of the heterozygous T/G genotype was evidenced by the presence of three fragments (372 bp, 219 bp and 153 bp), as shown in Figure 1.

\section{Statistical analysis}

The statistical package SPSS for Windows, version 21.0 was used. Allelic and genotypic frequencies were calculated for the total population evaluated and for the MS-DM2 and control groups. The $\chi^{2}$ test was used to compare frequencies and observed and expected values to evaluate the Hardy-Weinberg equilibrium (HWE). Means and medians were determined for biochemical, clinical and anthropometric characteristics accordingly. The normal distribution of the variables was verified by the KolmorgovSmirnov test. The comparison of the parametric variables with normal distribution was performed using Student's t-test, when 2 groups were compared and the Mann and Whitney U-test in those variables that had a non-normal distribution.
A p-value $<0.05$ was considered statistically significant. Likewise, a binary logistic regression was carried out in order to obtain the odd ratio adjusted to a confidence interval of $95 \%$, to estimate the relative risk of the variable under study. A p-value $<0.05$ was considered statistically significant.

\section{Results and discussion}

Study population characteristics

In this study, the $+45 \mathrm{~T}>\mathrm{G}$ polymorphism of the $A D I P O Q$ gene was associated with the development of MS and DM2 in adult individuals from Maracaibo City. No prior information was found on the association of that polymorphism of the $A D I P O Q$ gene with individuals diagnosed with MS and DM2. Complete raw data are available on $\mathrm{OSF}^{25}$.

Clinical, biochemical and anthropometric characteristics of both groups (MS +DM2 and control patients) are shown in Table 2. Statistically significant differences were found when comparing the means and medians in almost all studied characteristics, with the exception of height and usCRP. Most of the parameters of MS and DM2 individuals were found to be higher than in healthy controls, with exception of HDL-c levels. In line with the findings of the present study, DM2 patients in Brazil, India and Russia ${ }^{18,26,27}$ showed similar results in clinical characteristics, such as BMI, HOMA-IR, fasting glucose, TC, TG, HDL-c, LDL-c, systolic blood pressure (SBP) and diastolic blood pressure (DBP). Moreover, Sahli et al. ${ }^{28}$ reported statistically significant differences in BMI, fasting glucose, TC, TG, HDL-c, LDL-c, DBP, and SBP in a Tunisian population. However, a DM2 Chinese Han population ${ }^{29}$, showed no significant difference when comparing height and usCRP in diabetic and healthy control groups. These differences could be related to the heterogeneity of the

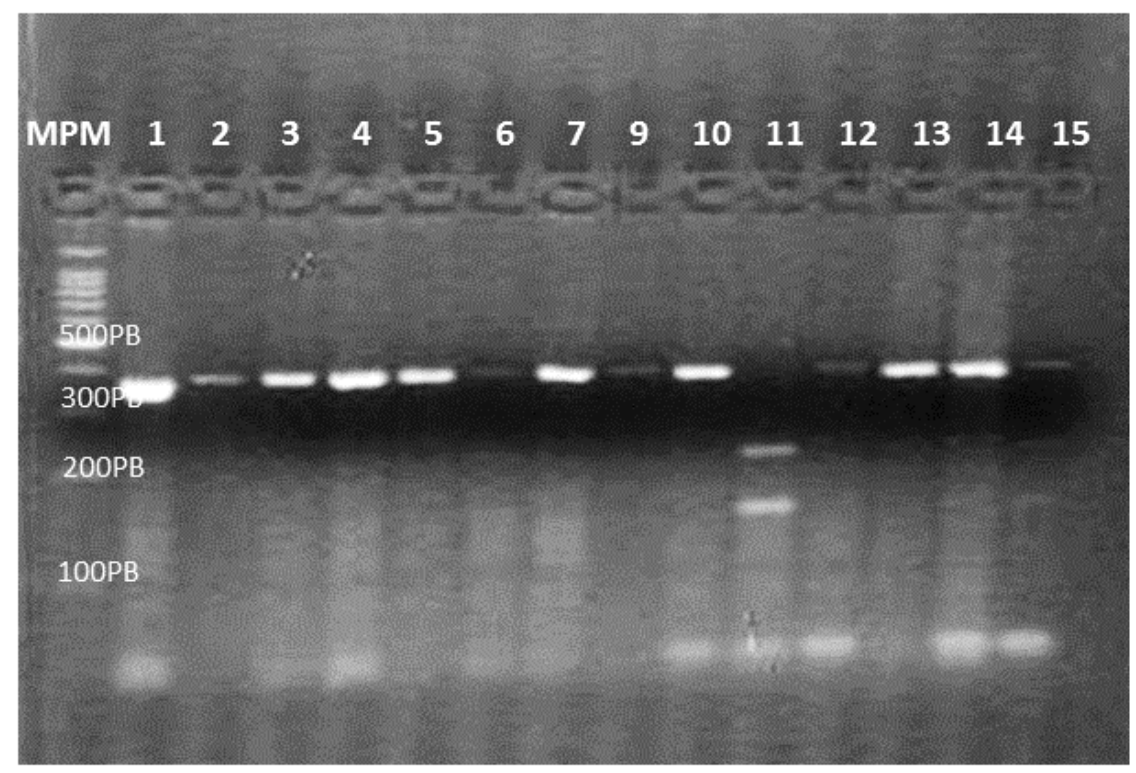

Figure 1. The 372 bp DNA fragment covering the region of interest amplified by PCR. The region of interest was amplified using this set of oligonucleotide primers: F5'-GAATGAGACTCTGCTGAGATGG-3' and R5'- TATCATGTGAGGAGTGCTTGGATG-3'. 
Table 2. Clinical and anthropometric characteristics of the subjects.

\begin{tabular}{|c|c|c|c|c|}
\hline Clinical characteristics & All & MS+DM2 (n=44) & Control group $(n=46)$ & $p$ value \\
\hline \multicolumn{5}{|l|}{ Gender } \\
\hline Female, $n$ & 35 & 18 & 17 & - \\
\hline Male, $\mathrm{n}$ & 55 & 28 & 27 & - \\
\hline Age (years) ${ }^{\star}$ & $37(17)$ & $54(9)$ & $21.5(3.5)$ & $0.000+$ \\
\hline Height (m) & $1.65(0.08)$ & $1.6(0.09)$ & $1.6(0.06)$ & $0.999+$ \\
\hline $\mathrm{BMI}\left(\mathrm{kg} / \mathrm{m}^{2}\right)$ & $25.9(4.8)$ & $31.5(2.8)$ & $21.9(1.4)$ & $0.000+$ \\
\hline WC $(\mathrm{cm})$ & $89.50(15.0)$ & $106.50(7.5)$ & $77.00(3.0)$ & $0.000 \dagger$ \\
\hline CRP & $0.54(0.4)$ & $0.712(0.5)$ & $0.364(0.3)$ & $0.47 \neq$ \\
\hline Fasting Insulin $(\mu \mathrm{UI} / \mathrm{I})^{*}$ & $13.7(4.6)$ & $17.2(4.5)$ & $10.5(2.9)$ & $0.000 \dagger$ \\
\hline HOMA-IR* & $2.3(0.9)$ & $3.1(1.05)$ & $1.5(0.4)$ & $0.000+$ \\
\hline $\mathrm{FG}(\mathrm{mg} / \mathrm{dl})^{*}$ & $130.5(39)$ & $166.7(44)$ & $89.5(6.5)$ & $0.000 \dagger$ \\
\hline TC (mg/dl) & $183.5(29)$ & $212.5(47)$ & $162(20.2)$ & $0.000+$ \\
\hline $\mathrm{TG}(\mathrm{mg} / \mathrm{dl})^{*}$ & $108.45(79)$ & $213(68.5)$ & $59(17.7)$ & $0.000 \dagger$ \\
\hline $\operatorname{HDLc}(\mathrm{mg} / \mathrm{dl})^{*}$ & $45(8)$ & $38.5(6)$ & $53(8.7)$ & $0.000+$ \\
\hline $\operatorname{LDLc}(\mathrm{mg} / \mathrm{dl})^{*}$ & $102.6(23.5)$ & $131.3(37.6)$ & $93.1(19.6)$ & $0.000+$ \\
\hline $\mathrm{SBP}(\mathrm{mmHg})$ & $120(10)$ & $130(15)$ & $110.0(4.2)$ & $0.000 \ddagger$ \\
\hline $\mathrm{DBP}(\mathrm{mmHg})^{*}$ & $75(7.5)$ & $80(9)$ & $70.0(6.7)$ & $0.000+$ \\
\hline
\end{tabular}

Values expressed as Median (interquartile range) unless indicated. *Variable expressed as logarithm. †Student's t-test for independent samples. $\ddagger$ Mann Whitney U-test. BMI, body mass index; WC, waist circumference; CRP, C-Reactive Protein; HOMA-IR, homeostatic model to estimate insulin resistance; FG, fasting glucose; TC, total cholesterol; TG, triacylglycerides; HDL-c, high-density lipoprotein cholesterol; LDL-c, low-density lipoprotein cholesterol; SBP, systolic blood pressure; DBP, diastolic blood pressure.

populations, due to the fact that they may have totally different lifestyles, including feeding, physical activity, environmental factors, and customs, among others.

\section{Frequency of $A D I P O Q$ genotypes}

Table 3 depicts the allelic and genotypic frequencies of the $+45 \mathrm{~T}>\mathrm{G}$ polymorphism of the $A D I P O Q$ gene, in patients with MS-DM2 and healthy control patients. The T/T genotype was found in greater frequency in the total population, although patients with MS-DM2 showed a greater frequency, as described by Sahli et $a l^{28}$ in a Tunisian MS population. T/G and G/G genotypes were found in both groups but showed lower frequencies. The healthy controls showed a genotypic frequency of $27 \%$ and $5 \%$ for the $T / G$ and $G / G$ genotypes, respectively, which indicates that the homozygous $\mathrm{T}$ genotype is three times higher in healthy individuals. Other studies generated opposite results ${ }^{26,27,30,31}$, since the $\mathrm{T} / \mathrm{T}$ genotype was found more frequently in healthy control patients than in DM2 ones.

\section{Allelic frequencies}

Regarding the alleles, a higher frequency of the $\mathrm{T}$ allele was observed over the $\mathrm{G}$ allele in both study groups, the $\mathrm{T}$ allele being more frequent in the population with MS-DM2, where the Hardy-Weinberg balance $\chi^{2}=5.99$ is met, because the observed allele frequencies are as expected. Such findings relate to the MS population studied in Tunisia ${ }^{28}$ but differ with the type 2 diabetes mellitus individuals studied in Brazil, India and
Ireland ${ }^{26,27,31}$ since the highest frequency of the $\mathrm{T}$ allele occurred in the healthy control group Table 4.

\section{Comparison of populations}

As shown in Table 4, the population that differ the most from the one characterized in this study, turned out to be the Brazilian one ${ }^{26}$, although Brazil is near Venezuela, the studied subjects were of Japanese ancestry; this could be the reason of such genetic differences although the lifestyles and customs are similar in both countries.

\section{Association of anthropomorphic characteristics with ADIPOQ status}

Table 5 shows that there was a significant difference among waist circumference, fasting glucose, total cholesterol, triacylglycerides, LDL-c, DBP and SBP, for the T/T and T/G + G/G genotypes regarding the total population. Those that had the presence of the $\mathrm{G}$ allele of the polymorphism exhibited lower values except for the usCRP in which those subjects that carried the $\mathrm{T}$ allele had lower levels in this parameter.

On the other hand, the control population (without MS-DM2) showed statistically significant difference regarding the DBP. In the MS-DM2, a significant difference was only observed in fasting insulin levels between groups. In addition, it was demonstrated that in these groups, the subjects who presented the $\mathrm{G}$ allele showed lower mean values than of those without 
Table 3. Allelic and genotypic frequencies of the $+45 T>G$ polymorphism of the $A D I P O Q$ gene in control patients and patients with MS and DM2.

\begin{tabular}{|l|l|l|l|l|l|l|l|}
\hline Genotype & \multicolumn{2}{|c|}{ Control Population } & \multicolumn{2}{l|}{ MS+DM2 } & \multicolumn{2}{l|}{ Total population } \\
\hline & $\mathbf{n}$ & Frequency (\%) & N & Frequency (\%) & n & Frequency (\%) \\
\hline T/T & 30 & 68.0 & 41 & 89.0 & 71 & 79 \\
\hline T/G & 12 & 27.0 & 4 & 9.0 & 16 & 18 \\
\hline G/G & 2 & 5.0 & 1 & 2.0 & 3 & 3 \\
\hline Total & 44 & 100 & 46 & 100 & 90 & 100 \\
\hline Allele & $\mathbf{n}$ & Frequency & N & Frequency & $\mathbf{n}$ & Frequency \\
\hline T & 72 & 0.82 & 86 & 0.93 & 158 & 0.88 \\
\hline G & 16 & 0.18 & 6 & 0.07 & 22 & 0.12 \\
\hline Total & 88 & 1.00 & 92 & 1.00 & 180 & 1.00 \\
\hline
\end{tabular}

MS, metabolic syndrome; DM2, type 2 diabetes mellitus.

Table 4. Allelic and genotypic frequencies in various populations.

\begin{tabular}{|l|l|l|l|l|l|l|}
\hline & \multicolumn{3}{|l}{ Genotype (\%) } & & Alleles & Study \\
Pocation (ref.)
\end{tabular}

MS, metabolic syndrome; DM2, type 2 diabetes mellitus.

this allele (homozygous T), except for the usCRP levels, which were higher in individuals with the $\mathrm{G}$ allele. Potapov et al..$^{18}$ obtained contradictory results in their study in a DM2 Russian population, since the fasting glucose levels showed higher values for subjects carrying the $\mathrm{G}$ allele, and in control subjects, a statistically significant difference was only found in SBP, which was higher in those individuals who carried the $\mathrm{G}$ allele.

\section{Previous studies}

Several studies have reported the behavior of several anthropometric, clinical and biochemical characteristics in their total populations concerning the $+45 \mathrm{~T}>\mathrm{G}$ polymorphism, finding opposite data that the one found during this study. In a non-diabetic female population in Greece ${ }^{16}$, fasting insulin and HOMA-IR levels were significantly lower in carriers of the rare $+45 \mathrm{G}$ allele $(\mathrm{T} /$ $\mathrm{G}+\mathrm{G} / \mathrm{G})$, which was also evidenced in Italian individuals with or without DM2 ${ }^{32}$, in non-diabetic individuals in Taiwan ${ }^{33}$, there were only significant differences in the BMI, with higher values for $\mathrm{T}$ allele carriers, unlike Punjab individuals ${ }^{34}$ who those that carried the $\mathrm{G}$ allele displayed higher BMI and $\mathrm{WC}$ values.

According to Menzaghi et al. ${ }^{35}$, the biology of these associations with anthropometric, clinical and biochemical characteristics is still unclear, for example, it is mentioned in their research that studies in animal models show that adiponectin is a potent insulin activator and modulator, in addition to regulating energy homeostasis and glucose tolerance. This relationship has also been found between the adiponectin levels in rodents and humans, which suggests that the $+45 \mathrm{~T}>\mathrm{G} A D I P O Q$ polymorphism can exert its action by diminishing or enhancing the expression of adiponectin, which can increase or decrease body weight and insulin resistance. In other populations, this variant may be 
Table 5. Association of the $+45 \mathrm{~T}>\mathrm{G}$ polymorphism of the ADIPOQ gene, according to MS-DM2 condition, with anthropometric, biochemical and clinical variables in the studied subjects.

\begin{tabular}{|c|c|c|c|c|c|c|c|c|c|}
\hline \multirow[b]{2}{*}{ Characteristics } & \multicolumn{2}{|c|}{ Control subjects } & \multirow[b]{2}{*}{$p$ value } & \multicolumn{2}{|c|}{ MS-DM2 } & \multirow[b]{2}{*}{$p$ value } & \multicolumn{2}{|l|}{ All } & \multirow[b]{2}{*}{$p$-value } \\
\hline & $T / T(n=30)$ & $T / G+G / G(n=14)$ & & $\begin{array}{l}T / T \\
(n=41)\end{array}$ & $T / G+G / G(n=5)$ & & $T / T(n=71)$ & $\begin{array}{l}T / G+G / G \\
(n=19)\end{array}$ & \\
\hline \multicolumn{10}{|l|}{ Gender } \\
\hline Female, $\mathrm{n}$ & 10 & 7 & - & 17 & 1 & - & 27 & 8 & - \\
\hline Male, $\mathrm{n}$ & 20 & 7 & - & 24 & 4 & - & 44 & 11 & - \\
\hline Age (years) & $21.5(3.50)$ & $21.00(2.50)$ & ${ }^{*} 0.338+$ & $\begin{array}{l}55.00 \\
(9.00)\end{array}$ & $45.00(2.00)$ & $0.427 \dagger$ & $44.00(18.50)$ & $\begin{array}{l}24.00 \\
(10.00)\end{array}$ & $0.002 \dagger$ \\
\hline Height (m) & $1.65(0.05)$ & $1.60(0.06)$ & $0.283+$ & $\begin{array}{l}1.66 \\
(0.11)\end{array}$ & $1.65(0.02)$ & $0.924 \dagger$ & $1.66(0.09)$ & $\begin{array}{l}1.62 \\
(0.06)\end{array}$ & $0.397 \dagger$ \\
\hline BMI & $22.2(1.52)$ & $21.21(1.75)$ & $0.468+$ & $\begin{array}{l}31.39 \\
(3.08)\end{array}$ & $33.92(1.85)$ & $0.145+$ & $26.61(4.37)$ & $\begin{array}{l}22.47 \\
(4.38)\end{array}$ & $0.113+$ \\
\hline WC $(\mathrm{cm})$ & $77.50(2.5)$ & $76.0(5.0)$ & $0.519+$ & $\begin{array}{l}106.00 \\
(7.0)\end{array}$ & $116.00(8.5)$ & $0.523+$ & $96.50(14.3)$ & $\begin{array}{l}79.00 \\
(10.5)\end{array}$ & $0.042 \dagger$ \\
\hline CRP & $0.364(0.32)$ & $0.356(0.45)$ & $0.315+$ & $\begin{array}{l}0.776 \\
(0.57)\end{array}$ & $0.670(0.05)$ & $0.365+$ & $0.541(0.49)$ & $\begin{array}{l}0.575 \\
(0.30)\end{array}$ & $0.938 \dagger$ \\
\hline $\begin{array}{l}\text { Fasting insulin } \\
(\mu \mathrm{UI} / \mathrm{L})\end{array}$ & $9(2.15)$ & $11.60(3.90)$ & ${ }^{*} 0.441 \dagger$ & $\begin{array}{l}17.00 \\
(3.80)\end{array}$ & $24.30(4.75)$ & $0.038+$ & $13.70(4.85)$ & $\begin{array}{l}13.50 \\
(4.23)\end{array}$ & $0.718+$ \\
\hline HOMA-IR & $1.3(0.40)$ & $1.70(0.60)$ & $0.848+$ & $\begin{array}{l}3.10 \\
(0.90)\end{array}$ & $4.40(1.25)$ & *0.291† & $2.40(0.90)$ & $\begin{array}{l}2.15 \\
(0.70)\end{array}$ & ${ }^{*} 0.818 \dagger$ \\
\hline $\begin{array}{l}\text { Fasting glucose } \\
(\mathrm{mg} / \mathrm{dl})\end{array}$ & $89.5(6.50)$ & $90.00(7.05)$ & $0.225+$ & $\begin{array}{l}168.00 \\
(43.00)\end{array}$ & $149.00(29.70)$ & ${ }^{*} 0.374 \dagger$ & $138.00(41.00)$ & $\begin{array}{l}102.00 \\
(21.75)\end{array}$ & ${ }^{*} 0.007 \dagger$ \\
\hline TC (mg/dl) & $164(22.00)$ & $157.00(20.50)$ & $0.546+$ & $\begin{array}{l}222.00 \\
(45.50)\end{array}$ & $177.00(21.50)$ & $0.070+$ & $192.00(36.00)$ & $\begin{array}{l}162.00 \\
(21.50)\end{array}$ & $0.001 \dagger$ \\
\hline TG (mg/dl) & $60.36(18.50)$ & $56.50(17.21)$ & $0.510+$ & $\begin{array}{l}217.00 \\
(59.50)\end{array}$ & $164.00(80.50)$ & ${ }^{*} 0.967 \dagger$ & $127.00(83.00)$ & $\begin{array}{l}77.00 \\
(29.00)\end{array}$ & ${ }^{*} 0.038 \dagger$ \\
\hline HDL-c (mg/dl) & $53(10.00)$ & $52.00(5.00)$ & $0.588+$ & $\begin{array}{l}39.00 \\
(6.50)\end{array}$ & $32.00(1.50)$ & $0.174 \dagger$ & $44.00(8.00)$ & $\begin{array}{l}50.00 \\
(6.00)\end{array}$ & $0.566+$ \\
\hline LDL-c (mg/dl) & $93.8(21.50)$ & $91.87(12.00)$ & $0.863+$ & $\begin{array}{l}138.54 \\
(39.45)\end{array}$ & $109.32(22.94)$ & $0.180+$ & $106.30(32.40)$ & $\begin{array}{l}94.40 \\
(13.70)\end{array}$ & $0.003+$ \\
\hline $\mathrm{SBP}(\mathrm{mmHg})$ & $110(7.50)$ & $110.00(5.00)$ & $0.060+$ & $\begin{array}{l}130.00 \\
(15.00)\end{array}$ & $130.00(7.50)$ & $0.864 \neq$ & $120.00(13.50)$ & $\begin{array}{l}110.00 \\
(3.50)\end{array}$ & $0.007 \ddagger$ \\
\hline $\mathrm{DBP}(\mathrm{mmHg})$ & $70(7.50)$ & $67.50(5.00)$ & $0.006+$ & $\begin{array}{l}80.00 \\
(9.00)\end{array}$ & $90.00(10.00)$ & $0.780+$ & $80.00(10.00)$ & $\begin{array}{l}70.00 \\
(5.00)\end{array}$ & ${ }^{*} 0.004 \dagger$ \\
\hline
\end{tabular}

Values expressed as median (interquartile range) unless indicated. *Variable logarithmically transformed for its normalization. + Student's t-test for independent samples; łMann-Whitney U-test. BMI, body mass index; CRP, C-reactive protein, HOMA-IR, homeostatic model to estimate insulin resistance, HDL-c, high-density cholesterol lipoproteins; LDL-c, low-density cholesterol lipoproteins; SBP, systolic blood pressure; DBP, diastolic blood pressure.

associated with DM2, obesity and MS, whereas in other association studies, insulin resistance and DM2 are a consequence of the presence of the T allele.

Additionally, a binary logistic regression model was used to determine the influence of the $+45 \mathrm{~T} / \mathrm{G}$ polymorphism of the $A D I P O Q$ gene on MS-DM2, where the odds ratio showed no association of this polymorphism as a risk factor predisposing to MS-DM2. The presence of the rare allele is considered a protection factor (Table 6). These findings oppose those previously reported by Stumvoll et $a .^{36}$ who studied non-diabetic
Table 6. Odds ratio (OR) of the variables related to metabolic syndrome (MS) and type 2 diabetes mellitus (DM2).

\begin{tabular}{|l|l|l|}
\hline Variables & OR & p value \\
\hline MS+DM2 & $0.261(0.085-0.085)$ & 0.019 \\
\hline DM2 & $0.319(0.109-0.935)$ & 0.037 \\
\hline MS & $0.261(0.085-0.805$ & 0.019 \\
\hline
\end{tabular}


Germans and recognized that the $+45 \mathrm{G}$ allele was associated with higher IR indexes. This led to lower insulin sensitivity compared to $\mathrm{T}$ allele carriers while those subjects who carried the polymorphism could present a higher risk of obesity. The same phenomenon was described in diabetics and non-diabetics in Northern India ${ }^{34}$; however, no association between $+45 \mathrm{~T} / \mathrm{G}$ polymorphism and the development of DM2 was found in Koreans individuals with and without $\mathrm{DM} 2^{37}$. The $\mathrm{G}$ allele of the $+45 \mathrm{~T}>\mathrm{G}$ polymorphism of the $A D I P O Q$ gene has been associated with endocrine-metabolic pathology in Chinese individuals with and without MS in a similar population, whereas in Tunisia no association of polymorphism with MS was found ${ }^{28,38}$.

Although there is a lack of consistency among studies, there is evidence that the $45 \mathrm{G}$ allele of the $A D I P O Q$ gene plays a protective role in MS and DM2, whereas the $45 \mathrm{~T}$ allele behaves as a risk allele for the development of obesity and insulin resistance, which are both related to the development of MS and DM2 $2^{32,33,39}$, consistent with the findings in this study.

The $+45 \mathrm{~T}>\mathrm{G}$ polymorphism of the $A D I P O Q$ gene is a silent mutation without its own biological effect, since it is a GGT to GGG substitution, which translates to Gly15Gly. Adiponectin's role in insulin sensitivity and BMI, as well as its role in both MS and DM2 pathologies are associated with genetic alterations linked to the polymorphism-related disequilibrium. mRNA $G$ allele transcripts vary, proving higher than those of $T$ allele of heterozygous individuals. This suggests that promoter gene polymorphisms or other adiponectin gene regulatory elements could be involved in the decrease or increase of the expression of the studied adipokine, being able to affect the mRNA allowing the stability of the splice sites in the same, affecting the amount of circulating protein $s^{28,30}$. It has also been observed that haplotypes that are in ligation unbalance with one or more functional variants can affect the levels of adiponectin in plasma, producing for example a change in the secondary structure of DNA, having a major influence on transcription, processing or translation; however, this is hypothetical, since the exact genetic mechanisms responsible for the expression of the specific allele have not been elucidated yet ${ }^{32}$.

\section{Conclusions}

In this study, biochemical, clinical and anthropometric characteristics corresponding to MS-DM2 were determined, and statistically significant differences were found between the means and medians of all the variables evaluated, except for height and usCRP. The genotype frequency of the $+45 \mathrm{~T} / \mathrm{G}$ polymorphism of the $A D I P O Q$ gene, in the total population evaluated, was $79 \%$ for the homozygous $\mathrm{T} / \mathrm{T}$ variant, $18 \%$ for the heterozygous $\mathrm{T} / \mathrm{G}$ variant and $3 \%$ for the homozygous $\mathrm{G} / \mathrm{G}$ variant. The allelic frequencies of the $+45 \mathrm{~T} / \mathrm{G}$ polymorphism were 0.88 for the $\mathrm{T}$ allele, while only 0.12 of the evaluated individuals exhibited the $\mathrm{G}$ allele.

Likewise, it was found that there is a statistically significant difference between the means and medians of WC, fasting glucose, total cholesterol, triacylglycerides, LDL-c, DBP and SBP, between genotypes $\mathrm{T} / \mathrm{T}$ and $\mathrm{T} / \mathrm{G}$ with respect to the total population. In addition, the total population with the $\mathrm{G}$ allele showed lower mean values for these variables than those without this allele (homozygous T), except for the values of CRP and HDL-c, which were higher in individuals with the $G$ allele. Overall, an association was found between the $+45 \mathrm{~T}>\mathrm{G}$ polymorphism of the ADIPOQ gene with MS-DM2. The results suggest that the presence of the $G$ allele exerts a protective effect on carrier individuals, thus preventing the onset of MS and DM2.

\section{Data availability}

Open Science Framework: Association between +45T\&gt;G adiponectin polymorphism gene and type 2 diabetes mellitus and metabolic syndrome in a Venezuelan Population. https://doi. org/10.17605/OSF.IO/3HE6S ${ }^{25}$.

The project contains the following extended data:

- Data Articulo.v3.xlsx (complete raw anthropometric data and $A D I P O Q$ status).

Data are available under the terms of the Creative Commons Zero "No rights reserved" data waiver (CCO 1.0 Public domain dedication).

\section{Grant information}

The authors acknowledge the "Consejo de Desarrollo Científico, Humanístico y Tecnológico" (CONDES) of La Universidad del Zulia for the financial support of this project (Project No. CC-0429-16).
1. Breitfeld J, Stumvoll M, Kovacs P: Genetics of adiponectin. Biochimie. 2012; 94(10): 2157-63.

PubMed Abstract | Publisher Full Text

2. Valero $P$, Souki A, Rodríguez NA, et al:- editors Valmore Bermúdez-Pirela Yaneth Herazo-Beltrán. Aspectos básicos en obesidad. Barranquilla: Ediciones Universidad Simón Bolívar; 2018.

Reference Source

3. Nigro $\mathrm{E}$, Scudiero $\mathrm{O}$, Monaco $\mathrm{ML}$, et al.: New insight into adiponectin role in obesity and obesity-related diseases. Biomed Res Int. 2014; 2014: 658913. PubMed Abstract | Publisher Full Text | Free Full Text

4. Fu Y: Adiponectin signaling and metabolic syndrome. Prog Mol Biol Trans/ Sci. 2014; 121: 293-319.

PubMed Abstract | Publisher Full Text

5. Elissondo N, Rosso L, Maidana P, et al.: Adiponectin: An adipocytokine with multiple protective functions. 2008 .

Reference Source 
6. Alberti KG, Eckel RH, Grundy SM, et al:: Harmonizing the metabolic syndrome: a joint interim statement of the International Diabetes Federation Task Force on Epidemiology and Prevention; National Heart, Lung, and Blood Institute; American Heart Association; World Heart Federation; International Atherosclerosis Society; and International Association for the Study of Obesity. Circulation. 2009; 120(16): 1640-5.

PubMed Abstract | Publisher Full Text

7. Ramírez-Bran DC, Contreras F: Prevalencia del Síndrome Metabólico. 2014 Reference Source

8. Alberti KG, Zimmet $\mathrm{P}$, Shaw J, et al:: The metabolic syndrome--a new worldwide definition. Lancet. 2005; 366(9491): 1059-62. PubMed Abstract | Publisher Full Text

9. Kaur J: A comprehensive review on metabolic syndrome. Cardiol Res Pract. 2014; 2014: 943162.

PubMed Abstract | Publisher Full Text | Free Full Text

10. Bermudez $\mathrm{V}$, Toledo $\mathrm{A}$, Leal $\mathrm{N}$, et al:: Prevalencia del síndrome metabólico en la población adulta Añú de la laguna de Sinamaica del municipio Páez, estado Zulia. 2009.

Reference Source

11. Rojas J, Bermúdez V, Añez R, et al:: Comportamiento Epidemiológico del síndrome metabólico en el municipio Maracaibo-Venezuela. Sindrome Cardiometebólico. 2013; 3(2).

Reference Source

12. Bermudez V, Salazar J, Rojas J, et al.: Prevalencia de diabetes mellitus tipo 2 y factores asociados en la ciudad de Maracaibo, Venezuela. Revista Latinoamericana de Hipertensión. 2014; 9(2): 14-25.

Reference Source

13. Whiting DR, Guariguata L, Weil C, et al.: IDF diabetes atlas: global estimates of the prevalence of diabetes for $\mathbf{2 0 1 1}$ and 2030. Diabetes Res Clin Pract. 2011; 94(3): 311-21.

PubMed Abstract | Publisher Full Text

14. OMS: Estadísticas Mundiales 2014. 2014. Report No.: 978924069269. Reference Source

15. OMS: Obesidad y sobrepeso. 2015 [cited 201522 de noviembre] Reference Source

16. Melistas L, Mantzoros CS, Kontogianni M, et al:: Association of the $+45 T>G$ and $+276 \mathrm{G}>\mathrm{T}$ polymorphisms in the adiponectin gene with insulin resistance in nondiabetic Greek women. Eur J Endocrinol. 2009; 161(6): 845-52. PubMed Abstract | Publisher Full Text | Free Full Text

17. Viso M, Porrello B, Rauseo D, et al:: Adiponectina y su relación con obesidad, insulinorresistencia y síndrome metabólico en adultos de la cohorte cdc de canarias en Venezuela. Rev Venez Endocrinol Metab. 2013; 11(2): 76-86. Reference Source

18. Potapov VA, Chistiakov DA, Dubinina A, et al:: Adiponectin and adiponectin receptor gene variants in relation to type 2 diabetes and insulin resistancerelated phenotypes. Rev Diabet Stud. 2008; 5(1): 28-37. PubMed Abstract | Publisher Full Text | Free Full Text

19. Orellana G, Sapunar J, Sáez K, et al:: Asociación entre polimorfismos del gen de adiponectina y estado nutricional en escolares de la comuna de Hualpén. Rev méd Chile. 2012; 140(10): 1245-52. Publisher Full Text

20. Hara K, Horikoshi M, Yamauchi T, et al.: Measurement of the high-molecular weight form of adiponectin in plasma is useful for the prediction of insulin resistance and metabolic syndrome. Diabetes Care. 2006; 29(6): 1357-62. PubMed Abstract | Publisher Full Text

21. Kishida K, Funahashi T, Shimomura I: Adiponectin as a routine clinica biomarker. Best Pract Res Clin Endocrinol Metab. 2014; 28(1): 119-30. PubMed Abstract | Publisher Full Text

22. American Diabetes Association: (2) Classification and diagnosis of diabetes. Diabetes Care. 2015; 38 Suppl: S8-S16. PubMed Abstract | Publisher Full Tex

23. Miller SA, Dykes DD, Polesky HF: A simple salting out procedure for extracting DNA from human nucleated cells. Nucleic Acids Research. 1988; 16(3): 1215. PubMed Abstract | Publisher Full Text | Free Full Text

24. Krízová J, Dolinková M, Lacinová Z, et al.: Adiponectin and resistin gene polymorphisms in patients with anorexia nervosa and obesity and its influence on metabolic phenotype. Physiol Res. 2008; 57(4): 539-46. PubMed Abstract

25. Hoedebecke K: Association between +45T\&gt; G adiponectin polymorphism gene and type 2 diabetes mellitus and metabolic syndrome in a Venezuelan Population. 2019. http://www.doi.org/10.17605/OSF.IO/3HE6S

26. Vendramini MF, Pereira AC, Ferreira SR, et al:: Association of genetic variants in the adiponectin encoding gene (ADIPOQ) with type 2 diabetes in Japanese Brazilians. J Diabetes Complications. 2010; 24(2): 115-20. PubMed Abstract | Publisher Full Text

27. Saxena M, Srivastava N, Banerjee M: Genetic association of adiponectin gene polymorphisms $(+45 T / G$ and $+10211 T / G)$ with type 2 diabetes in North Indians. Diabetes Metab Syndr. 2012; 6(2): 65-9. PubMed Abstract | Publisher Full Tex

28. Sahli S, Khlifi L, Jaballah A, et al.: Evaluation of serum adiponectin and ADIPOQ $+45 \mathrm{~T}>\mathrm{G}$ polymorphism with metabolic syndrome in tunisian population. IJPSR. 2017; 8(3): 1294-3000 Publisher Full Text

29. Du W, Li Q, Lu Y, et al.: Genetic variants in ADIPOQ gene and the risk of type 2 diabetes: a case-control study of Chinese Han population. Endocrine. 2011 40(3): 413-22.

PubMed Abstract | Publisher Full Text

30. Esteghamati A, Mansournia N, Nakhjavani M, et al:: Association of $+45(T / G)$ and $+276(G / T)$ polymorphisms in the adiponectin gene with coronary artery disease in a population of Iranian patients with type 2 diabetes. Mol Biol Rep. 2012; 39(4): 3791-7.

PubMed Abstract | Publisher Full Text

31. Al Hannan FA, O'Farrell PA, Morgan MP, et al:: Associations between singlenucleotide polymorphisms of $A D I P O Q$, serum adiponectin and increased type 2 diabetes mellitus risk in Bahraini individuals. East Mediterr Health J. 2016; 22(8): 611-8.

PubMed Abstract | Publisher Full Text

32. Menzaghi C, Ercolino T, Di Paola R, et al.: A haplotype at the adiponectin locus is associated with obesity and other features of the insulin resistance syndrome. Diabetes. 2002; 51(7): 2306-12.

PubMed Abstract | Publisher Full Text

33. Yang WS, Tsou PL, Lee WJ, et al:: Allele-specific differential expression of a common adiponectin gene polymorphism related to obesity. $J$ Mol Med (Berl). 2003; 81(7): 428-34.

PubMed Abstract | Publisher Full Text

34. Matharoo K, Arora P, Bhanwer AJ: Association of adiponectin (AdipoQ) and sulphonylurea receptor $(A B C C 8)$ gene polymorphisms with Type 2 Diabetes in North Indian population of Punjab. Gene. 2013; 527(1): 228-34. PubMed Abstract | Publisher Full Text

35. Menzaghi C, Trischitta V, Doria A: Genetic influences of adiponectin on insulin resistance, type 2 diabetes, and cardiovascular disease. Diabetes. 2007; 56(5): resistance, $1198-209$.

1198-209.
PubMed Abstract | Publisher Full Text

36. Stumvoll M, Tschritter O, Fritsche A, et al:: Association of the T-G polymorphism in adiponectin (exon 2) with obesity and insulin sensitivity: interaction with family history of type 2 diabetes. Diabetes. 2002; $51(1): 37-41$. PubMed Abstract | Publisher Full Text

37. Lee YY, Lee NS, Cho YM, et al:: Genetic association study of adiponectin polymorphisms with risk of Type 2 diabetes mellitus in Korean population. Diabet Med. 2005; 22(5): 569-75.

PubMed Abstract | Publisher Full Text

38. Li X, Wei D, He H, et al:: Association of the adiponectin gene (ADIPOQ) $+45 \mathrm{~T}>\mathrm{G}$ polymorphism with the metabolic syndrome among Han Chinese in Sichuan province of China. Asia Pac J Clin Nutr. 2012; 21(2): 296-301.

PubMed Abstract | Publisher Full Text

39. Ukkola O, Ravussin E, Jacobson $\mathrm{P}$, et al:: Mutations in the adiponectin gene in lean and obese subjects from the Swedish obese subjects cohort. Metabolism. 2003; 52(7): 881-4.

PubMed Abstract | Publisher Full Tex 


\section{Open Peer Review}

\section{Current Peer Review Status:}

\section{Version 1}

Reviewer Report 21 May 2019

https://doi.org/10.5256/f1000research.18466.r47149

(C) 2019 Pourmotabbed T. This is an open access peer review report distributed under the terms of the Creative Commons Attribution License, which permits unrestricted use, distribution, and reproduction in any medium, provided the original work is properly cited.

\section{Tayebeh Pourmotabbed}

Department of Microbiology, Immunology and Biochemistry, University of Tennessee Health Science Center (UTHSC), Memphis, TN, USA

Adiponectin is a secretory protein and the most plentiful adipokine in circulation. It induces insulin sensitivity, has anti-inflammation and anti-atherogenic effects. Its low concentration is associated with an increase in body fat mass, insulin resistance and dyslipidemia. Adiponectin gene polymorphism has been shown to affect protein production and thus, its plasma concentration. In this manuscript, the authors have studied association between $+45 T>G$ polymorphism of the adiponectin gene (ADIPOQ) and risk of type 2 diabetes (DM2) and metabolic syndrome (MS) in subjects from Maracaibo municipality, Zulia state in Venezuela. Their data suggest that presence of the $\mathrm{G}$ allele at this position of adiponectin gene may protect the carrier individuals against MS and $\mathrm{DM} 2$, at least in this population.

The study is well thought of and well written, worth indexing. However, since low adiponectin level is associated with DM2 and MS and adiponectin gene polymorphism affects protein production; in the case of sample availability and technical support, it would be interesting to measure the level of adiponectin in the studied population. In addition, the presence of $\mathrm{G}$ allele may have an effect on stability of adiponectin RNA and thus the protein level, thus, determining the level of adiponectin RNA by semiquantitative PCR may shed some light on protective role of G allele.

Is the work clearly and accurately presented and does it cite the current literature? Yes

Is the study design appropriate and is the work technically sound? Yes

Are sufficient details of methods and analysis provided to allow replication by others? Yes

If applicable, is the statistical analysis and its interpretation appropriate? 
Yes

Are all the source data underlying the results available to ensure full reproducibility? Yes

Are the conclusions drawn adequately supported by the results?

Yes

Competing Interests: No competing interests were disclosed.

Reviewer Expertise: Gene therapy, biochemistry, gene polymorphism studies

I confirm that I have read this submission and believe that I have an appropriate level of expertise to confirm that it is of an acceptable scientific standard.

Reviewer Report 08 May 2019

https://doi.org/10.5256/f1000research.18466.r47649

(c) 2019 Zhu N. This is an open access peer review report distributed under the terms of the Creative Commons Attribution License, which permits unrestricted use, distribution, and reproduction in any medium, provided the original work is properly cited.

\section{Na Zhu}

Columbia University, NYC, USA

Major concern:

1. In table 2, there is a significant age difference between case and control, it should be a covariate.

2. The precision of the p-value is not precise, I suggest the author try other tools for the statistical test to get higher precision.

3. In table 3, the allele frequency of this polymorphism varied among populations. The allele frequency of $\mathrm{G}$ in controls matched with the Latino population frequency in gnomAD. The allele frequency of $\mathrm{G}$ in cases is lower than gnomAD Latino population frequency but higher than African and Finnish. So, the ancestry is very critical for such analysis. How did the author decide the ancestry of each sample?

4. Even the cases were completely Latino descents, as the cohort is small, the confidence interval of T's AF is large, it could be possible to result in a higher frequency of T with $p$ value $>0.001$.

5. In table 3, no association was present in the genotypic association or allelic association using a chi-square test. They also showed in table 6.

6. In table 4, the frequency in Ireland case and controls cohort reversed with the author's cohort, they also mentioned in the text, how did the author to explain it?

Minor concern:

1. In the section "Frequency of ADIPOQ genotypes", it said, "the homozygous T genotype is three times higher in healthy individuals". How was it from? I saw three times heterozygous 
T/G, was it a typo? If yes, it was not significant at all.

2. In table 2, I guess the age show median and interquartile range, then * should not be here.

3. In table 4, there is a typo, G's frequency 0.08 in healthy Ireland and Tunisia study.

4. Several typos happened in table 5 , the symbol is not consistent between case and control such as $p$-value in age, HOMA-R, and SBP.

5. Table 5 has duplicated information as table 2, they may be able to optimize their presentation.

Overall, I think the writing and the calculation are correct. However, the evidence they supplied cannot support their conclusions, such as no association between case and control and contrary finding among studies. $+45 \mathrm{~T}>\mathrm{G}$ is a polymorphism, the presence of its frequency in case and control could occasionally happen for such a small cohort. It is not convincing to draw the conclusion that the phenotypic difference resulted from $+45 \mathrm{~T}>\mathrm{G}$, this could be due to other common or rare variants.

Is the work clearly and accurately presented and does it cite the current literature? Yes

Is the study design appropriate and is the work technically sound? Partly

Are sufficient details of methods and analysis provided to allow replication by others? No

If applicable, is the statistical analysis and its interpretation appropriate? Partly

Are all the source data underlying the results available to ensure full reproducibility? Yes

Are the conclusions drawn adequately supported by the results? No

Competing Interests: No competing interests were disclosed.

Reviewer Expertise: Bioinformatics, association study in human genetics

I confirm that I have read this submission and believe that I have an appropriate level of expertise to confirm that it is of an acceptable scientific standard, however I have significant reservations, as outlined above.

Reviewer Report 07 May 2019

https://doi.org/10.5256/f1000research.18466.r47504 
(C) 2019 Mehanna E. This is an open access peer review report distributed under the terms of the Creative Commons Attribution License, which permits unrestricted use, distribution, and reproduction in any medium, provided the original work is properly cited.

\section{Eman T. Mehanna}

Department of Biochemistry, Faculty of Pharmacy, Suez Canal University, Ismailia, Egypt

The authors studied the relation of $+45 T>G$ adiponectin gene SNP and the parameters of type 2 diabetes mellitus and metabolic syndrome a Venezuelan population. They found that the rare $G$ allele of this polymorphism may be protective against most of those parameters.

Comments:

1. The title should be modified to: (Association of $+45 T>G$ adiponectin gene polymorphism with type 2 diabetes mellitus and metabolic syndrome in a Venezuelan population).

2. The language of the manuscript should be revised. Sometimes, the authors repeat sentences. For example, in the statistical analysis, the sentence (A p-value $<0.05$ was considered statistically significant) was repeated twice.

3. I did not understand the purpose of Table 6. I think genotype and allele frequencies should have been compared in the study groups using chi square test to assess the relation of the polymorphism with the development of metabolic syndrome.

4. In the legend of Figure 1, please define the genotype of each lane in the figure. Genotype TG is not clear at all due to the relatively faint bands.

5. The conclusion is very long. I suggest summarizing it and mentioning only the important findings of the study.

Is the work clearly and accurately presented and does it cite the current literature? Partly

Is the study design appropriate and is the work technically sound? Yes

Are sufficient details of methods and analysis provided to allow replication by others? Yes

If applicable, is the statistical analysis and its interpretation appropriate? Partly

Are all the source data underlying the results available to ensure full reproducibility? Yes

Are the conclusions drawn adequately supported by the results?

Yes

Competing Interests: No competing interests were disclosed.

Reviewer Expertise: Biochemistry and Molecular Biology 
I confirm that I have read this submission and believe that I have an appropriate level of expertise to confirm that it is of an acceptable scientific standard.

The benefits of publishing with F1000Research:

- Your article is published within days, with no editorial bias

- You can publish traditional articles, null/negative results, case reports, data notes and more

- The peer review process is transparent and collaborative

- Your article is indexed in PubMed after passing peer review

- Dedicated customer support at every stage

For pre-submission enquiries, contact research@f1000.com 